\title{
Being cool or being good: researching mobile phones in Mozambique
}

By Julie Soleil Archambault (SOAS)

Drawing on my fieldwork experience in Inhambane, Southern Mozambique, where I conducted research on mobile phone use amongst youth, my paper tackles issues of acceptance and rejection. As I sought to gain acceptance amongst youth I found myself participating in various controversial and, at times, dangerous activities that made me the victim of intense gossip and outright rejection by some. The fact that I came to the field accompanied by my husband and daughter only made matters worse. In this paper, I present the challenges of "being cool", while also "being good", and the repercussions of my research choices on my social standing. I then discuss how, instead of compromising my research, this predicament had a positive outcome by revealing social dynamics that might otherwise have remained hidden, namely the importance of concealment and the ambiguous role mobile phones play in deceit.

Lulu, a young Mozambican man, told me one afternoon that he wished he could go somewhere where nobody knew him, so that everyone would notice him and see how cool he was. After some time in the field, I also had the same desire, but for the opposite reason: I longed to pass unnoticed. I start this paper by presenting the challenges of acceptance and rejection I faced while conducting research on mobile phone use in Southern Mozambique. I then reflect on my personal experience and show how gossip and broken friendships made me more attuned to the importance of concealment, while also providing insight into the ambiguous role mobile phones play in deceit.

\section{Researching mobile phones}

When I first arrived in Inhambane, in Southern Mozambique, and started building contacts for my research, most people I met offered to exchange mobile phone numbers. They usually looked at me incuriously when I told them that I did not have a phone. Yes, I was one of those who swore they would never own one. In the field, however, I soon realised, to my initial dismay, that acquiring a phone was going to prove imperative. So, for research's sake, I got my first mobile phone. Before long, I became fascinated with phone use, and then something spectacular occurred: the city of Inhambane was subjected to a complete makeover. At the end of 2006, Mozambique's two mobile phone operators undertook an aggressive publicity campaign in which the facades of shops and bars, along with decaying concrete walls and other decrepit buildings were either painted in bright yellow and turquoise (the colours of mCel, the country's leading operator) or blue, white and red (the colours of 
Vodacom, mCel's competitor). In Inhambane, about one quarter of the buildings were repainted, some perhaps for the first time since colonial days. The visual effect was dramatic.

Inhambane is a small provincial capital of just over 50000 inhabitants situated in Southern Mozambique. It is known as the Land of Good People (Terra da boa gente), an attribute inherited from Vasco da Gamma, in homage to the hospitality he received when he visited the area in 1498. When I first went to Inhambane as a graduate student in 2001, it figured prominently in local identity discourses, but when I returned in 2005 to undertake dissertation research, things had changed. Throughout the year and a half I spent conducting fieldwork there, I heard many people remark that Inhambane was no longer the Land of Good People. These comments were part of broader discourses concerning the rapidly changing post-socialist, post-war context in which initial euphoria (cf. Isaacman 1978) had given way to disenchantment.

These comments also came up in discussions regarding mobile phones which, in only a few years, had become omnipresent. According to a survey I later conducted, for instance, $71 \%$ of grade 12 students (with an average age of 20) in the city of Inhambane were mobile phone owners in 2007. And so I eventually came to the realisation that an in-depth look at mobile phone use was needed, were I ever to understand the youth social realities that I had set out to study. I therefore gave up the research project I had neatly designed in London (on the intertwined nature of Pentecostalism, alcohol use, and conversion) and what I first saw as a nuisance became a research tool and, eventually, also a research object.

Liberdade, the neighbourhood where most of my research was carried out and where I also resided, starts after the abandoned railroad track, where the once paved road ends and the palm-lined sandy road known as Rua Branca begins. Diverging from the road, one enters a maze of narrow paths formed by tall braided palm-leave fences that delineate the different households. In Liberdade, like in other peri-urban areas of Inhambane, residents live in close proximity, as land is scarce and expensive, especially since the area absorbed many of the people displaced by the war in the late 1980s and early 1990s. This said, it does not have the hustle and bustle or the anonymity usually associated with an urban environment. Most houses are made out of local materials, and although an increasing number have corrugated iron roofs and electricity, only a few have running water. Most households rely on urban agriculture and/or petty trade, along with social networks, to supplement meager incomes, and many periodically face alimentation problems. Few of the young adults I worked with had founded independent households and most were living with their parents, often in women-headed households. Some were attending school, others had recently graduated, a handful had a regular source of income from employment, and many were "not doing anything", but all aspired to a similar lifestyle in which the consumption of modern consumer goods figured prominently. Aged between 19 and 29 , they were at a crossroads concerning education, intimate relationships, household formation and livelihood strategies.

Gaining access and acceptance amongst these young adults, or what I simplified as "being cool", proved relatively easy. Of course, my new phone, a second-hand lowrange Nokia, was not sufficient to ensure my acceptance; I also had to learn how to look cool, act cool and talk cool. I started spending most of my time in various youth spaces, from the public tap to the disco, and, before, long, I developed relationships 
with a number of youth who were keen on teaching me the local slang and on providing fashion advice.

\section{Gossip, broken friendships and the bad wife}

Before going to Mozambique, I wrote in the methods section of my research proposal that I believed my accompanying husband and five-year-old daughter would play an important part in my research, not only by making me, the researcher, appear somewhat normal, but also by facilitating my access to different groups of people. Drawing on the experiences of other anthropologists who conducted research in similar circumstances, I expected their presence to greatly help my entry in the field and to increase rapport (DeWalt and DeWalt 2002:62-3). This could not have been further from the truth.

In fact, I wish I had read Notes on Love in a Tamil Family before going to the field (Trawick 1990). Like Margaret Trawick's husband, my husband found little interest in following me around while I worked and much preferred staying at home with our daughter or hanging out with the other expatriates. In Inhambane, a good wife is expected to spend most of her time at home. A number of husbands admit that they are willing to spend money on television sets in order to ensure their wives do not always end up at the neighbour's house come novela time (Brazilian soap operas that run in the late afternoons and evenings). This control of women's movements is intimately linked to a control over female sexuality. Unlike men, for whom it is expected yet contested to have multiple partners, a woman is not supposed to have more than one partner. Of course, a woman can sneak out while her husband is away, but the idea of a woman going out, especially at night, while leaving her husband at home, is simply inconceivable. As foreigners we were allowed a certain leeway, but still, my behaviour, along with my husband's permissiveness, prompted great interest and comment, especially from neighbours and older residents of our neighbourhood.

Despite these murmurs, my research amongst younger unmarried adults was progressing nicely, and the amount of time I spent away from home increased proportionately. However, after being attacked one night at machete point - a very traumatic event that nearly cost me my precious mobile phone - I was forced to rethink my research strategies. I therefore went searching for someone who could act as my research assistant-cum-body guard. After a couple of unsuccessful trials, I eventually met Hernane, a 24-year-old man who had just completed secondary school and who proved very enthusiastic. My association with Hernane kept me safe. At the same time, it further facilitated my access to local youth as it allowed me to hang out with other young men from the neighbourhood who often gathered at his house in the afternoons to lift weights and converse (bater papo). On the other hand, however, it had serious repercussions on my social standing, since it provided further content for the rumours which were already circulating and which thus became ever more contemptuous.

Shortly after arriving in Inhambane, I met Benedita (as I will call her here), a married woman who had two children and who was the same age as me. We paid regular visits to each other and, often in the company of Isabella, her sister-in-law, spent countless afternoons sitting in the shade and talking about intimate relationships. Benedita's husband was an unrelenting womaniser and Isabella's, a heavy drinker. Both husbands were extremely jealous and forbade their wives to own a mobile phone for 
fear that they would contact and be contacted by other men. I would listen to them fantasise about one day finding a better man, and the different pressure tactics they developed to get what they wanted in the meantime. Our relationship was such that I was amongst the few to know that they both had secret lovers and I was usually informed of new developments. This was before my research really picked up, when I was still spending a lot of time at home, when I was still a relatively good wife.

However, later in my research, when I was spending much more time away from home, Benedita and Isabella became my most vocal critics and even ended up severing ties with me altogether. Their husbands played a large part in this rejection as they reportedly forbade them to socialise with me. They saw me as a bad influence. This said, I knew both women were not exactly very compliant, something they had proven to me on a number of occasions (both eventually raised enough money behind their husbands' back to get their own mobile phones), and I believe they could easily have maintained our friendship had they wanted to, even as a form of defiance. They were not the only ones, however, to disapprove of me. Whenever I met older acquaintances, it was common for them to greet me politely and then to add: " $a h$, passear...", which meant "oh, so you are out on a stroll [again]". What they were implying was that I was not being a good wife.

Gossip involves a degree of secrecy but it also only achieves its full potential when disclosed. The very neighbours who were responsible for spreading gossip about me were happy to translate others' comments when we appeared together in the streets. The novelty of the tsungu ("European" in Gitonga, the local language) woman living in an all-black peri-urban neighbourhood eventually wore off, and instead of saying "look at the tsungu passing by", residents turned to comments like "here comes the woman who never stays at home". When my house got burglarised, my neighbours blamed my habit of hanging out with youth. "She went looking for it", they reportedly commented amongst each other. Meanwhile, the young adults I was essentially interested in were opening up to me, involving me in intimate disputes and even phone theft. My research was going great, yet I was left with mixed feelings.

Then one night, at $11 \mathrm{pm}$, I received a text message from an unknown number saying: "I am waiting for you. I love you". When I showed the message to a group of young women the following day, they all agreed that someone was trying to break up my marriage. It could have been a wrong number; who knows? Still, I felt awful. Were there really people who disliked me so much as to attempt to sabotage my relationship with my husband? My romantic image of the anthropologist being friends with everyone was shattered. I felt cornered, I wanted to disappear, perhaps even find a new field site.

After initial frustrations, I asked myself why it was that I provoked such resentment amongst older residents in the neighbourhood and, more importantly, I tried to make sense of what it all meant. Elizabeth Colson (1953) and Max Gluckman (1963) understood gossip as contributing to group unity, and, in Gluckman's words, as being essentially about "the evaluation of morals and skills" (Gluckman 1968:34). In this perspective, gossip could be understood to act as a conservative and leveling force. By discussing my behaviour amongst themselves, my older acquaintances were reinforcing social values and reminding each other how to behave appropriately. But what was appropriate behaviour, then, if others appeared to be doing much worse than me? How could Benedita and Isabella be so critical of me when they were secretly cheating on their husbands? I could appreciate that spending so much time out of my 
home raised criticism and suspicion. I had nothing to hide though, and considered that by being open and transparent about my activities, I was somehow proving that what I was doing was "morally" acceptable. Was gossip, like Robert Paine (1967) argued, about furthering one's individual interests? Were Benedita and Isabella gossiping about me in order to detract attention from their own illicit doings?

I believe the issue was more subtle: it was not so much what I did as how I did it that mattered. It had to do with discreetness, local understandings of respect and the etiquette of deceit.

\section{Discreetness, the etiquette of deceit and the invisible realm of mobile phone communication}

Horst and Miller (2006) remarked, with regards to relationships in Jamaica, that "one can reach a point where people see a lie as a kind of higher 'truth' because as an exposure of deceit it brings a person closer to reality, while a mere truth is seen as the continuation of what must really be deceit" (Horst and Miller 2006:98-9). At first, this made little sense to me, but, as I came to better understand relationships in Inhambane where deceit is also rife, I found their observations to be right on the mark. In other words, little, if anything, can be taken at face value, and as such, a good lie is better than a "truth". As Inocencio explained to Sandra, two youths I worked with: "You girls are used to being lied to and you force us to lie. Women prefer to be lied to, and when you speak the truth to them, they don't believe you, so it's better to lie." And so my predicament gave me insight into the etiquette of deceit: honesty or transparency that convey an unlikely sense of genuineness is seen as a serious lack of respect.

In Inhambane, respect and discreetness are often used interchangeably, and telling lies becomes somewhat acceptable when done to preserve respect. As an inebriated young man insightfully put it during a monologue in a bar, "lying exists to facilitate the propagation of the human race". A good partner is therefore not necessarily a faithful one, but rather a discreet one. "Quem esconde é porque gosta" (one who conceals does so because he/she cares), women often commented half-cynically. Benedita reiterated this when we were still friends. She said: "Our fathers also used to have lovers, but at least they got them far away, now our husbands go with the 'neighbours'." Discreetness is all the more valued given the difficulty involved. In the peri-urban areas of Inhambane privacy is hard to come by, and evading the ubiquitous gaze of other residents is a tricky task that is only partially resolved by erecting a tall fence around one's property (cf. Reed 1999). In order to survive such a hostile gossiping environment, one has to be clever (experto-a). Owning a mobile phone might also help.

In recent years, close attention has been paid to the ways in which mobile phones in particular, and information and communication technologies (ICTs) in general, are redefining and reconstructing experiences and understandings of time and space (Castells 2000, Ling and Pedersen 2005, Maroon 2006). For many, the "perpetual contact" granted by mobile phones has been perceived as intrusive; various studies have reflected on the invasion of the public space with private talk, and argued that growing mobile phone use was leading to a decline of the public sphere and a correlated erosion of privacy (see the edited volume by Katz and Aakhus 2002). However, the "communication revolution" (Osborn 2008:317) currently underway in Southern Mozambique appears to be occasioning quite the opposite by providing 
individuals with a level of privacy that many had never even dreamed of (see also Hahn and Kibora 2008, Ito 2005, and Maroon 2006). Indeed, local discourses are all about evaluating the mobile phone's effects on intimate relationships. In Inhambane, like in most of sub-Saharan Africa, land-line infrastructure remains weakly developed and most people have passed "from no phone to cell phone" (Orlove 2005: 699). As such, a mobile phone is not a better telecommunication tool; it is a tool that makes telecommunication possible often for the very first time, thus opening up entirely new spaces and possibilities.

In Inhambane, normative discourses paint a strict sexual division of courtship in which men are defined as the active players. They are the ones who have to demonstrate their interest and their worthiness to the women they like, while the latter are expected to feign complete disinterest. Before mobile phones, that is, only a few years ago, opportunities for young men and women to meet and flirt were rather limited and courtship was usually a mediated affair. Young men relied on family members or neighbours to make their interests in a woman known. Wedding negotiations were usually the preserve of fathers and uncles, thus excluding, at least to some extent, the couple concerned (Junod 1966). For those who preferred more direct communication, there was the possibility of sending love letters, but, as many recalled, the time delay was often demotivating. Young men would also "hunt" women by hanging out in the alleys leading to the market. Many still do. Being a public space, however, the alley offers serious restrictions as a courtship space. With the entry of mobile phones, courtship has become less mediated, more personal, much easier (in theory, at least) and, ultimately, more private. As Fakira, a young Mozambican man explained: "Before, when I wanted to talk to a girl I liked, I would risk getting beaten by her brothers or her boyfriend. Now, I just phone her!"

In a context where privacy is scarce and where discreetness is highly valued, the invisible realm of mobile telecommunication becomes invaluable to the consolidation and management of intimate relationships away from the gaze of family members, neighbours and other partners. As a result, relationships are consolidated, which might not have been, were it not for mobile phones. What is more, multiple relationships become easier to manage (cf. Horst and Miller 2006). Owing to the creation of this new space, endeavours to transcend the state of surveillance that characterises daily life become more successful, and the power relations reproduced through this control, more easily challenged. Like fences, however, phones often provide only a false sense of privacy. They might help conceal secrets, but they can as easily reveal them by providing proofs of unfaithfulness, through intercepted phone calls or text messages.

\section{When connections backfire}

Despite it being expected of men to have multiple partners, this does not prevent women from getting upset when unfaithfulness is disclosed. In such cases, the accused usually attempts to convince the woman in question that her suspicions are only based on unfounded rumours. One of the problems with mobile phones is that they leave traces and therefore provide material proofs of infidelity that cannot as easily be dismissed as rumours, even if sometimes they might really be wrong numbers or from people who are "only friends".

A very popular song from the Angolan signer Maya Cool recounts the story of a woman who picks up her husband's ringing phone only to find a message saying: 
"Darling, I want to see you" (Querido quero te ver). In the rest of the song, the husband attempts to justify the text message to his wife: he says he only gave the sender of the message a ride. The singer then criticises "young cheeky girls" (pequenas atrevidas) who just want to destroy families (lares) and laments the problems caused by mobile phones ("telemóvel, hoje em dia, é motivo de problema"). The song ends with a dialogue between the husband $(\mathrm{H})$ and the young girl $(\mathrm{G})$ who sent the text message:

H: Não me liga mais (Don’t phone me anymore), he pleads

G: Vou ligar (I will phone), she answers

H: Tenho mulher (I have a wife), he says

G: Não quero saber (I don't care), she tells him

In this song the man is portrayed as the victim of cheeky young girls, and ultimately, of his mobile phone. The song speaks for the experience of many. In Inhambane, everyone, young and old, has a story about themselves or a couple they know who split up "because of the mobile phone" ( $\mathrm{po}^{\prime} \mathrm{ca}$ ' do telefone). This type of misunderstanding is in fact described as the mobile's biggest drawback. At first, it may seem that Mozambicans are victims of technological determinism when they place the blame on the phone rather than on unfaithfulness. But when youth in Inhambane say that so-and-so broke up "because of the phone", they are rather underscoring that the biggest harm comes from lack of discreetness and from the fact that the tangible proofs the phone provides are almost impossible to deny.

When I asked how they deal with jealousy, young women commonly answered that "If you seek, you find" (Quem procura, encontra). In other words, women were aware that their partner was likely to have other partners and that if they set out to look for proofs, they were bound to find some. And so, as long as they could turn a blind eye, this is what they tended to do. In fact, in Inhambane, phone investigation is not as pronounced as in other places (see, for example Horst and Miller 2006). Young adults see themselves as civilized - a recurrent theme in identity discourses - and describe phone investigation as something someone "without education" would do. For this reason, many claim to obey a strict "no touching the other's phone" rule with their partners, a rule which rests on respect, not trust. More than anything, it reflects a certain acceptance of existing social contradictions and an attempt to prevent, or at least minimise, conflict. Whether the rule is respected is obviously hard to tell and so most nevertheless regularly delete messages and clear call logs, just in case. Still, many get caught inadvertently. For the young adults I worked with, there were only limited "legitimate" occasions that called for switching one's phone off. For that reason, a disconnected phone automatically roused suspicion. Unlike "proofs" that are acquired through investigation, "proofs" that are stumbled upon have added weight because they really place the deceived as a victim, unlike the investigator, who purposefully went out looking for "trouble" (confusão).

The interception of a suspicious call or message, just like encountering a disconnected phone, usually triggers a heady argument. It brings couples to talk (and scream) about issues that might otherwise not be taken seriously. Young women now have stronger claims to voice their concerns as these are based on tangible proofs instead of rumours, and as such, they are not as easily dismissed. And so, phone use in Inhambane opens up new discursive spaces in which the terms of intimate relationships can be negotiated. What is more, while pressuring men to be 
monogamous and faithful, a number of young women I worked with have also come to the conclusion that they could attain a better lifestyle by engaging in relationships with various men. From a female perspective, the phone therefore acts as both a discursive and a practical tool used to challenge existing power relations, not so much to topple them, but rather to act upon their ramifications. Young men, for their part, are often torn between jealous sentiments and the need to turn a blind eye to the dissolution of their claim to exclusivity, given that most do not dispose of the material base on which it rests.

\section{Being cool or being good?}

In Southern Mozambique, the mobile phone comes at a time when intimate relationships, household formation and gender hierarchies are being redefined, alongside changing consumption patterns. The phone is also seen by many as intensifying these transformations. Indeed, mobile phone practices are both reflective and constitutive of broader socio-economic reconfigurations and can therefore serve as an original avenue to explore broader social dynamics. Had I left my family behind or had I worked on a different topic, I might have been spared the criticism. Then again, my neighbours would probably have found something else to talk about. Gossiping is, after all, a great form of entertainment. Instead of compromising my research, my personal experiences of acceptance and rejection helped me make sense of values that might otherwise have remained obscure. They also added an experiential twist to my research as I started to use my mobile like many Mozambicans do: to manage and keep separate different spheres of my life (cf. Horst and Miller 2006). The phone allowed me to operate more discreetly, while also keeping me safe. It helped me to reduce the traffic of youth who came to pick me up at my house, and opened up an invisible, or at least, a less visible, realm within which to conduct my research. Still, the challenges of "being cool" while also "being good" were never entirely reconcilable.

\section{References}

Castells, M. 2000. End of Millennium (The information age: Economy, society and culture III). Oxford: Blackwell.

Colson, E. 1953. The Makah Indians. Manchester: Manchester University Press.

DeWalt, K.M. and B.R. DeWalt. 2002. Participant observation: A guide for fieldworkers. Walnut Creek: Altamira.

Gluckman, M. 1963. Gossip and scandal. Current Anthropology 4, 307-16.

- 1968. Psychological, sociological and anthropological explanations of witcheraft and gossip: a clarification. Man, N.S. 3, 20-34.

Hahn, H.P. and L. Kibora. 2008. The domestication of the mobile phone: Oral society and new ICT in Burkina Faso. Journal of Modern African Studies 46, 87-109.

Horst, H.A. and D. Miller. 2006. The cell phone: An anthropology of communication. Oxford: Berg.

Isaacman, A. 1978. A Luta Continua: Creating a New Society in Mozambique. Binghamton: State University of New York. 
Ito, M. 2005. Mobile phones, Japanese youth, and the re-placement of social contact. In Mobile communications: Re-negotiation of the social sphere (eds) R. Ling and P.E. Pederson, 131-48. London: Springer.

Junod, H.A. 1966. The life of a South African tribe, Volume I. New York: University Books.

Katz, J.E. and M. Aakhus, eds. 2002. Perpetual contact: Mobile communication, private talk, public performance. Cambridge: Cambridge University Press.

Ling, R. and P.E. Pedersen, eds. 2005. Mobile communications: Re-negotiations of the social sphere. London: Springer.

Maroon, B. 2006. Mobile sociality in urban Morocco. In The cell phone reader: Essays in social transformation (eds) A. Kavoori and N. Arceneaux, 189-204. New York: Peter Lang.

Orlove, B. 2005. Editorial: Time, society, and the course of new technologies. Current Anthropology 46, 699-700.

Osborn, M. 2008. Fuelling the flames: Rumour and politics in Kibera. Journal of Eastern African Studies 2, 315-27.

Paine, R. 1967. What is gossip about? An alternative hypothesis. Man, N.S 2, 278-85.

Reed, A. 1999. Anticipating individuals: Modes of vision and their social consequence in a Papua New Guinea prison. Journal of the Royal Anthropological Institute 5, 46-56.

Trawick, M. 1990. Notes on love in a Tamil family. Berkeley: University of California Press.

\section{Acknowledgments}

An earlier version of this paper was presented at the 9th Annual Researching Africa Day Workshop, St Anthony's College, Oxford, 26 April 2008. The section on deceit was also part of a paper I presented at the 2008 AAA Annual Meeting in San Francisco entitled "Cell phones and the etiquette of deceit in Southern Mozambique".

\section{About the author}

Julie Soleil Archambault is currently writing her PhD thesis at the School of Oriental and African Studies (University of London) on mobile phone practices and secrecy amongst youth in Southern Mozambique. Her research interests include youth, communication, social navigation, desire, secrecy and the circulation of goods. She can be contacted at jisa@soas.ac.uk 